\title{
Regulation between Legal Norms and Economic Reality
}

\author{
Intentions, Effects, and Adaption: The German and American Experiences \\ Ed. by Günther Schulz, Mathias Schmoeckel and William J. Hausman
}

[Die Regulierung von Wirtschaft zwischen historischer Prägung und Normierung. Absichten, Folgen, Anspassung: die deutschen und amerikanischen Erfahrungen.]

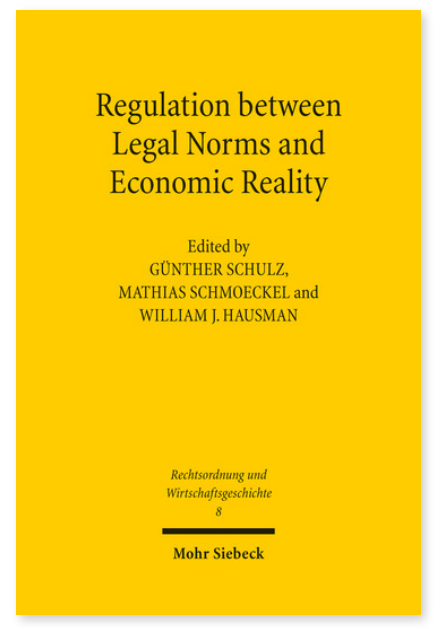

2014. IX, 328 pages. ROWG 8

ISBN 978-3-16-152248-2 sewn paper $79,00 €$

ISBN 978-3-16-160613-7 eBook PDF 79,00€
Published in English.

Currently, the terms regulation and deregulation are on everyone's lips. However, historical attempts to solve the problem of natural monopolies ranged between two extremes. On the one hand there was the government regulation of private companies in the U.S., and on the other hand there was government provision or nationalization of companies in Germany and most of continental Europe. At the interface between legal and economic history, this volume, the result of a GermanAmerican conference, focuses on the regulation of natural monopolies in network industries such as railways, energy or telecommunications. It analyzes constitutional and legal frameworks and investigates the development of markets and the political influence exerted by market participants. All historical moments lead to broader questions about regulation in its cultural-historical context, including the general principles underlying public regulatory policy in law, economics and society as well as existing path dependences. Hence, the volume provides a transnational and intercultural dialogue about the different characteristics and cultural interpretations of markets and market economies as well as their roles in society.

\section{Survey of contents}

Günther Schulz: Introduction - Mathias Schmoeckel: Liberty in or for the Market? The legal response to »big business « in the United States and Germany - Markus Wagner: Legal Perspectives and Regulatory Philosophies on Natural Monopolies in the United States and Germany - Andreas Their: Different Paths - same Direction. Comment on Markus Wagner: Legal Perspectives and Regulatory Philosophies on Natural Monopolies in the United States and Germany - Frank Schorkopf: Constitutional Principles and Regulation in Germany - Bill Novak: Law and the social control of American Capitalism - Markus Patt: The Rise and Fall of Regulatory authorities. A US-German comparison for the late 19th century railroad sector. Comment on Frank Schorkopf: »Constitutional Principles and Regulation in Germany « and Bill Novak: »Law and the Social Control of American Capitalism« - James W. Ely Jr.: Railroad Regulatory Policy in the Nineteenth Century - Boris Gehlen: Between Regulation and Nationalization. The Influence of Interest Groups on Railways, Telecommunications, and Electricity Industry Legislation in Germany, 1871-1935 - Roman Michalczyk: Comment on James Ely: »Railroad Regulatory Policy in the Nineteenth Century« and Boris Gehlen: »Between Regulation and Nationalization: The Influence of Interest Groups on Railways, Telecommunications, and Electricity Industry Legislation in Germany, 1871-1935«- Marc Levinson: Evasion as a driving force in U.S. transport deregulation - Katja Fuder: Comment on Marc Levinson: »Evasion as a Driving Force in U.S. Transport Deregulation - Alfred C. Mierzejewski: Comparing Apples and Oranges: A Comparison of American and German Railways - Mark H. Rose: Comment on Alfred C. Mierzejewski, „Comparing Apples and Oranges: The Historical Development of Railways in the United States and Germany« - Johannes Rüberg: A Tale of Fraternal Twins: German vs. U.S.

Telecommunications in the 20th Century - Klaus Ferdinand Gärditz: The Creation of Regulated Competition Markets and the Rise of Bureaucratic Autonomy in the German Law of Telecommunications - Christian Maurer: Comment on Klaus Ferdinand Gärditz: »The Creation of Regulated Competition Markets and the Rise of Bureaucratic Autonomy in the German Law of Telecommunications« - William J. Hausman/John L. Neufeld: Regulation and Restructuring of the U.S. Electric Utility Industry in the 20th Century - Alexandra von Künsberg-Langenstadt: The powers behind the thrown - Reasons for the persistence of the regulated electricity industry in Germany - Thomas Züll: Comment on Will Hausman/John L. Neufeld: »Regulation and Restructuring of the U.S. Electric Utility Industry in the 20th Century« and Alexandra von Künsberg-Langenstadt: »The Powers behind the Throne - Reasons for the Persistence of the Regulated Electricity Industry in Germany, 1950-1980«

Günther Schulz ist Professor für Verfassungs-, Sozial- und Wirtschaftsgeschichte an der Universität Bonn.

Mathias Schmoeckel Geboren 1963; Studium der Rechtswissenschaft in Bonn, Genf und München; 1993 Promotion; 1999 Habilitation; Geschäftsführender Direktor des Instituts für Deutsche und Rheinische Rechtsgeschichte und Bürgerliches Recht, sowie des Rheinischen Instituts für Notarrecht.

https://orcid.org/0000-0003-1504-4228

William J. Hausman ist Chancellor Professor of Economics at the College of William \& Mary, Williamsburg, Virginia, USA.

\section{Order now:}

https://www.mohrsiebeck.com/en/book/regulation-between-legal-norms-and-economic-reality-9783161522482?no_cache=1 order@mohrsiebeck.com

Phone: +49 (0)7071-923-17

Fax: $+49(0) 7071-51104$ 